\title{
Data from investigation on seismic Sea-waves events in the Eastern Mediterranean from the Birth of Christ to 500 A.D.
}

\author{
Part 1
}

\section{J. Antonopoulos *}

Received on July 1 st, 1980

\section{SORT SUMMARY}

The action at our coasts of the tsunamis, that is the sea waves caused by earthquakes, sudden landslides in the bottom of the sea or at the coast and very rarely by eruptions of submarine volcanoes, is not quite known even among specialists. What has been written on various occasions as regards this phenomenon is very little in relation to the more extended research in other parts of the globe.

The data collected and appearing in this work are expected to fill in a small part of the existing shortage of knowledge.

It should be pointed out that similar works as well as research as to the more general nature of the phenomenon have recently been initiated in many countries at an intensive rate; this has been the result of the increase both in volume and number of settlements and works in general on the coast where such waves often cause great destruction and human casualties.

We can therefore say that this work is quite opportune.

The work commenced with an investigation into ancient texts, archives publications, hydrographic and eterorological observations, oceanographic data and sources in general which are related to the phenomenon. The information collected helped in the preparation of the events of tsunamis

* Dept. of Civil Engineering. University of Patras. Patras (Greece). 
from the Birth of Christ to $1980 \mathrm{AD}$. The cases were registered in the text in an order by date of occurrence; the location of occurrence, the cause and the extent of each phenomenon depending on the damage caused are shown in separate columns. Where the cause was an earthquake, the epicentre is also indicated.

Finally, the respective events are shown in a map of Eastern Mediterranean so that the distribution of the action of this phenomenon in this part of the globe and the particular intensity with which it appears in certain parts are rendered clear.

\section{SOMMARIO}

L'azione sulle nostre coste degli tsunamis, cioè delle onde marine provocate dai terremoti, da smottamenti improvvisi sul fondo del mare o lungo le coste e, molto raramente a causa di eruzioni sottomarine, non c̀ completamente conosciuta anche fra gli specialisti. Quello che è stato scritto in varie occasioni circa questo fenomeno è assai poco in relazione alle più estese ricerche realizzate in altre parti del mondo.

I dati raccolti che compaiono in questo lavoro cercano di riempire una piccola parte delle deficienze esistenti nella conoscenza del fenomeno.

Deve essere messo in evidenza che lavori simili, come la ricerca concernente la natura più generale del fenomeno, sono stati recentemente iniziati in molti Paesi a ritmo intenso, questo è dovuto all'aumento e in volume $\mathrm{e}$ in numero degli insediamenti e delle strutture fatti in genere sulle coste dove tali onde causano spesso gravi distruzioni e vittime.

Possiamo quindi dire che questo lavoro è molto opportuno.

Il lavoro comincia con un'indagine in antichi testi, archivi, pubblicazioni, osservazioni idrografiche ed eterologiche, dati oceanografici e sorgenti in genere relative al fenomeno. Le informazioni raccolte sono state di aiuto nella documentazione degli eventi di tsunamis dalla nascita di Cristo al 1980 DC.

Gli eventi sono stati registrati nel testo secondo la data di evenienza; la località dove sono avvenuti, la causa c l'estensione di ogni fenomeno in relazione al danno causato sono scritti in colonne separate. Quando la causa ì stata un terremoto, ì anche indicato l'epicentro.

Infine, i rispettivi eventi sono stati riportati in una mappa clel Medicerranco Orientale in modo da rendere chiara la distribuzione dell'azione di questo fenomeno in questa parte del globo e la particolare intensità con cui si è verilicato in alcune parti.

\section{ABSTRACT}

The Eastern Mediterranean has a long history of damaging seismic sea waves (Tstmamis) but a great number of them which are locally generated 
are small. They have caused no serious damage to the coasts because their energy is confined by many islands of the Greek Archipelagos. However, some of them have been rather severe and destructive to property and human life.

This paper is comprised of data from an investigation into the activity of seismic sea waves in the Eastern Mediterranean from the Birth of Christ to 500 A.D. It contains a great amolint of information concerning earthquakes, volcanic eruptions and seismic sea waves.

All the available information has been compiled from historical accounts, archives, press reports, magazines and related works.

\section{RIASSUNTO}

Il Mediterraneo orientale ha una lunga storia di danni causati da maremoti (tsunamis), ma un gran numero di questi originatisi localmente, sono piccoli. Gli tsunamis non hanno causato seri danni nelle coste, perché la loro energia risulta in parte attenuata dalle molte isole dell'Arcipelago Greco tuttavia, alcuni di essi sono stati abbastanza gravi e distruttivi e per le strutture e per le vite umane. Il lavoro consiste di dati ot tenuti da un'indagine sull'attività dei maremoti nel Mediterraneo orientale, e comprende i seguenti periodi:

Part 1) dalla nascita di Cristo al 500 d.C.

Part 2) dal 500 d.C. al 1000 d.C.

Part 3) dal 1000 d.C. al 1500 d.C.

Part 4) dal 1500 d.C. al 1800 d.C.

Part 5) dal 1800 d.C. al 1900 d.C.

Part 6) dal 1900 d.C. al 1980 d.C.

Contiene un gran numero di informazioni relative a terremoti, eruzioni vulcaniche e maremoti.

Tutte le informazioni utili sono state raccolte da resoconti storici, archivi, articoli giornalistici, riviste e lavori manoscritti.

\section{INTRODUCTION}

Tsunamis from the Birth of Christ to 500 A.D. in the Eastern Mediterranean between 31-44 N and 18-36 E excluding Black Sea and the Italian coasts of the Adriatic Sea is the object of the present paper.

The terms "tidal wave " and "tsunami " are often used instead of the term « seismic sea waves». The first term is rather misleading, since seismic sea-waves are very rarely connected with tides. The term "tsunami », derived from the Japanese, seems to have been universally accepted. 
The research made so far on the origin and development of seismic sea-waves can be classified into two broad categories; theoretical studies and observational analyses. Theoretical studies, necessarily, involve oversimplified assumptions, and their results although have been proved helpful in understanding certain phases of the phenomenon, they have not as yet disclosed any particularly interesting fundamental characteristic of the phenomenon itself. Observational analyses seem to be more effective in particular when supplemented by theoretical findings, but due to the scanty of observational data they are rarely successfully applicable.

In undertaking an observational study of the origin of seismic sea-waves we sought primarely that the region over which we were to carry out our investigation should satisfy two conditions. First that the number of individual seismic events in this region should be as large and well documented as possible, and second that the region should be more or less self-contained of limited cxtent and geotectonically well documented.

In preparing our paper we were fully aware that its outcome would be more suggestive than definitive. Also we were aware of the fact that the older historical accounts of seismic phenomena rarely include much useful information other than reports of the fact that the older historical accounts of seismic phenomelabours.

\section{KEY TO DESCRIPTIONS OF EVENTS}

The description of events is arranged in the following manner.

Dates are given in headlines in the new style (Gregorian). They are followed by the name of the region in which the seismic sea-wave was felt. This is followed by the name of cities, towns or areas which were particularly affected. The intensity, $m$, of the wave is given in small roman numerals and it refers to Sieberg's modified intensity scale. Where the height of the wave on land or the distance which it flooded inland is known, and indicated as $(A=)$ and $(L=)$ respectively. Next the geographical coordinates of the epicentre of the main earthquake shock, when 
known, are given together with the intensity of the shock $(I=$ in the modified Mercalli scale), magnitude ( $M=$ after Gutenberg) and the focal depth ( $d=, s$ : shallow, $n$ : normal, $i$ : intermediate). This is followed by the references consulted which are pertinent to the Phenomenon itself, to the accompanying earthquake, and to the information necessary for the dating of the event. Numerals outside the parentheses, refer to references in the Bibliography. In the parentheses, roman numerals refer to the book (liber) and the following numbers to the chapter and line respectively of the text. $P$ : refers to a standard system of pagination while $p$ : indicates the page. Folio is indicated by $f$. Page references to an authority is not given when the material in that authority is arranged chronologically. Entries marked with an asterisk are doubtful events quoted mostly by modern writers, which have been included for the sake of completeness.

Place names mentioned in the originals, suffered many changes during historical and recent times. When these differ from those of today, the former are shown in brackets where they first occur, and the modern name is used thereafter. Modern places are spelt after Lippincott.

In what follows the headlines more information is given mainly about the last events. For all the other events only a bare outline is given.

With so many dates, controversial points, so many foreign names and such a multitude of references as crowd this paper; though we have done our best to be as accurate as possible, many errors must necessarily have crept in. We shall feel most greateful to those who will point these out to us.

\section{DESCRIPTION OF EVENTS}

\section{1. $46^{*}$ AD. South Coasts of Crete. 43 (p. 217), cf. 41.}

Sieberg (1932) refers to a seismic shock in Crete which was accompanied by a seismic sea-wave. This, he implies, was connected with the eruption of the volcano at Thera (Santorini) in $46 \mathrm{AD}$.

In spite of our search in early literature we have been unable 
to justify Sieberg's reference to a seismic sea-wave in Crete, or in any other place in the Grecian archipelago, for this date.

It seems probable that Sieberg obtained this information from Raulin (1869), whom he quotes as a general reference in his catalogue for the Cretan earthquakes. If this is the case, then for this event it is obvious that Sieberg was mislead by Raulin whose source of information for the $46 \mathrm{AD}$ sea-wave is Savary (1788). Savary's work lacks in chronological consistancy. He mentions a sea-wave and an earthquake in Crete for this year which he justifies by quoting Septimius (Epistle at Arcadius), Suidas, and Philostratus (Vita Apollonii). It is not difficult to check these references, in which case one finds that these three writers refer to three different events which took place at three different times, and that the seismic sea-wave is that of $62 \mathrm{AD}$.

We do not exclude the possibility that Sieberg's original reference for this sea-wave was not Raulin.

\section{62 AD. South Coasts of Crete. Lebena (iii). 5 (iv, 34), 30.}

According to Philostratus, when Apollonius of Tyana visited Leben near Phaestos in Crete, a strong earthquake shook the island and the sea at Leben retreated about one mile. A few days later, he says, the news arrived that on the very same day of the earthquake and just at the same hour of midday an island rose out of the sea between the islands of Thera (Santorini) and Crete (Vita Apollonii, lib. iv, cf. 34).

The date of this event we can not place very accurately. From Philostratus we know that Apollonius was at Olympia seven years before Nero attempted to cut the isthmus of Corinth (Vita Apoll., lib. iv, cf. 24). That attempt was made on 01.211.3= $67 \mathrm{AD}$, which fixes this visit to $01.210=$ July $61 \mathrm{AD}$. Apollonius after the Olympic games (01.210) is at Sparta till the end of the winter and in the spring of $62 \mathrm{AD}$ he proceeds to Crete. Although we do not know how long he stayed in Crete, where he witnessed the earthquake at Leben, we know that he arrived in Rome after a long journey from Crete in $64 \mathrm{AD}$ (Clinton, p. $49 \mathrm{R}$ ). It seems probable that the event which he describes should have taken place at the end of 62 or $63 \mathrm{AD}$, most probably in $62 \mathrm{AD}$ since 
Leben was one of the first places he visited after his arrival in Crete (1).

Many writers and in many catalogues we found the island which is mentioned by Philostratus identified with the islet of Hiera, which emerged between Thera (Santorini) and Theressia during one of the early eruptions of the volcano of Thera. This chronologically is possible. According to Dio Cassius, Hiera (2) appeared in the reign of Claudius (between 42 and $54 \mathrm{AD}$ ). Dio, furthermore, says that at the time Valerius Asiaticus was consulate which fixes the year in $46 \mathrm{AD}$ (Histor. Roman., lib. ix, of 27). Aurelius Victor notes moreover that the island emerged at night during an eclipse of the moon (lib. ii), which Calvisius (p. 444) dates in December $46 \mathrm{AD}$ and Bourger (1657) either in January 1,47 or December $31,46 \mathrm{AD}$. There is a general agreement in early texts (3) that Hiera should have emerged in $46 \mathrm{AD}$, and, and if we disregard Pliny's dating (4) we can prove by refering to Cedrinos (p. 197, c, d) that when Hiera emerged Apollonius was in Byzantium on his way to India and not in Crete.

It is clear to us that the island of Hiera emerged in $46 \mathrm{AD}$ and that the earthquake and the accompanying sea-wave at Leben, which is described by Apollonius, occurred in $62 \mathrm{AD}$. There remains, however, to identify the island alluded to by Apollonius, which should have been connected with the sea-wave at Leben.

(1) Gutenberg (1932), Sieberg (1932) and those refering to these two catalogues date this event in $66 \mathrm{AD}$. Marinatos (1939) dates in $60 \mathrm{AD}$ and only Schmidt (1879) gives 62 AD. Most writers of this event have, most probably, been mislead by Raulin (1869) who transcribed Savary (1788).

(2) It seems most probable that this island was not Hiera but Theia. Fouque (1879).

(3) Orosius, lib. vii, cf. 6; Seneca, Quest. Natur., lib. ii, cf. 25.6, Dio Cassio, lib. lx, cf. 29, Eusebius, Eccl. Hist. lib. ccxi, 4.

(4) Pliny dates the appearance of Hiera in July 5, 3 AD while at the same time he says that the event was reported to the consulates Marcus Junius Silanus and Norbanus Balbus, who, as a matter of fact, did not become consulates until $19 \mathrm{AD}$. Apart from this chronological inconsistan$c y$, we know that during an early transcription of Pliny's works, events of the CXXXXV Olympiad were dated in the CXXXV O1., apparently a misprint of the time which complicates matters further. 
For this, we resort to Bursian (1862, p. 522) who very logically suggests that there might have been a volcanic shoal or islet near Thera (Santorini) which following the behaviour not so uncommon with islets around Thera, sunk shortly after it emerged from the sea.

As for the origin of the seismic sea-wave observed at Leben, we may say that is was of volcanic nature.

3. $76^{*}$ AD. Cyprus. Cition, Paphos and Salamis. 39 (p. 139), 44 (p. 775), 15 (vii), 18 (P. 342), 20 (P. 277), 14 (P. 54), 22 (vii, 9.11), 30 (p. 459), 9 (P. 248).

A disastrous earthquake occured in Cyprus in 76 or $77 \mathrm{AD}$. This earthquake is generally dated together with a pestilence in Rome, in $77 \mathrm{AD}$, but early chroniclers differ in it slightly (1). We are inclined to think rather of $76 \mathrm{AD}$ as the year for this earthquake because this was the year at which the Romans transfered their mint to Cyprus and the first coins minted there are dated July 76, August 77 and September 78 (Hill 1940, p. 234). It is not improbable that this transfer of the mint was connected with the measures taken to relieve the island after the earthquake which is generally dated $767 \mathrm{AD}$ but may have taken place a year earlier. Some few early chroniclers may have put the earthquake in $77 \mathrm{AD}$ in order to synchronise it with the pestilence in Rome.

The facts about the particular places in Cyprus which were clestroyed by this earthquake and the seismic sea-wave which is supposed to have accompanied this earthquake, are very obscure.

If we trust the allusion in the Sibyllina Oracula (lib. iv, lines $125,126,140,141)$, the places in Cyprus which suffered most

(1) Hieronymos (Vita Hilarion, § 7), Sungelos (p. 342), St. Jerome, Chron. Paschale (p. 248D), Orosius (lib. vii, § 9.11), Calvisius (p. 459) place the pestilence in Rome and the earthquake in Cyprus in $77 \mathrm{AD}$, Eusebios (Armenian Text, Chron. p. 277) and Elias Nisibinus (Chron. transl. by Delaporte, p. 54) place the pestilence in this year but the earthquake between July 75 and July 76 AD. Suetonius (Titus ch. 8) and Victor (Epit. p. 367) refer this to the reign of Titus. 
should have been Salamis, Paphos and Cition, but it is questionable whether these places suffered from the $76 \mathrm{AD}$ earthquake or from a later shock. It seams probable, from the slight indications, mostly inferences from statements at a later date, that, with the possible exception of Cition, Salamis and Paphos should have been damaged to some extent by the $76 \mathrm{AD}$ earthquake. The chroniclers were evidently not quite certain of the particular places in Cyprus which were damaged by this earthquake.

The Sibyllina Oracula prophesies also a destructive seismic sea-wave (lib. iv, lines 126, 140; lib. v, lines 450-453; lib. vii, line 5). This prophesy constitutes the sole authority upon which Oberhummer (1903, p. 139) (1) and after him many authors have based their arguments for the $76 \mathrm{AD}$ seismic sea-wave in Cyprus. But we find no mention of such an event in the narrations of early chroniclers (2), and we feel that should an event such as a catastrophic seismic sea-wave had in fact accompanied this earthquake, it should have been most certainly included by these chroniclers in their description of the seismic events of $76 \mathrm{AD}$.

Whether, in this instance, the Sibyllina Oracula can be trusted as a source of authentic historical information, and if so, whether the seismic sea-wave in Cyprus which is mentioned in the text refers to the earthquake of $76 \mathrm{AD}$, all yet remains to be

(1) The Greek text of the Oracle (lib. iv, lines 140, 141) which appears in Obernummer's work (p. 139, lines 10 and 11) should read:

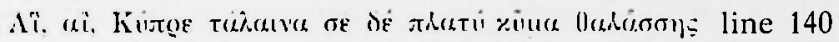

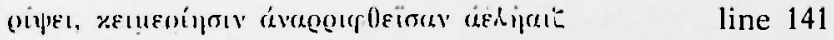

(= Alas suffering Cyprus, you shall be laid waste by the broad whirling waves of the sea which are tossed up in the winter)

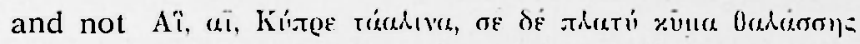

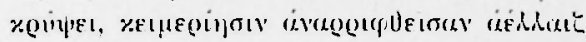

(= Alas suffering Cyprus, the broad waves of the sea which are tossed up whirling in the winter will cover over you).

(2) The difference is very important wince now this oracle does not seem to refer to a seismic sea-wave, but rather to one of the hurricanes which are known to have burst over the island during its early history Casola (1498), Anonymous (1546 a,b) Lusignan (1580) and others.

Also Oberhummer's standard pagination of the oracles is throughout by three lines too high. 
investigated. No other data worthy of any confidence has come to our attention.

4. 142 AD. Island of Rhodes (iv), Islands of Kos, Seriphos and Syme (iii), 19, 4 (viii, 43.3), 2 (ix, 1), 1 (iv, 14.4) 33, 34, 36.

An earthquake in the island of Rhodes is mentioned by Pausanias (lib. viii, § 43.3) which he says devastated the city of Rhodes. The same event is mentioned by Julius Capitolinus (Ant. Pius, lib. ix, § 1) who says that this occurred in the reign of Antonius Pius. Hertzberg (1866) would place this earthquake in 142 or $141 \mathrm{AD}$ to which Loewy (1888) and Herberdey (1890) agree.

This earthquake is mentioned by many other writers (1), none of which however, notices that it was followed by a seismic sea-wave. An extensive reference to the sea-wave which accompanied the $142 \mathrm{AD}$ earthquake, we found in the Greek text of an oration by the rhetorician Aelius Aristides (Rhodiakos, xliii, § 340374). If we can trust Aristides's account (2), the city of Rhodes was practically devastated not so much by the earthquake as by the sea-wave which followed. Towns in the islands of Cos, Seriphos and Syme suffered heavily from both the earthquake shock and the ensued sea-wave. In Rhodes the sea advanced many miles inland and rased to the ground what ruins were left standing by the shock proper.

It is of interest to note that a proof of this earthquake we found in the Corpus Inscriptionum Graecarum, for we learn from an inscription dated in $142 \mathrm{AD}$ that after the earthquake the town of Stratonicea in Caria which was destroyed by the same earthquake received financial aid from the emperor (CIG, Nr. 2721).

It is not difficult to show that the earthquake occurred after the spring of $142 \mathrm{AD}$. It is also possible to show that this event

(1) Dapper (1681); Waddington (1867); Keil (1898); Boulanger (1923); Lockwood (1935); Wicks (1960).

(2) According to Boulanger, this oration does not belong to Aristides but 10 one of the sophistae of his school. The same view is also held by Keil. 
should have taken place before the end of $142 \mathrm{AD}$. This, we learn from an inscription, dated 7 November $142 \mathrm{AD}$ in which the council of the city of Rhodes expressed its gratitude for the assistance offered to Rhodes (Inscriptiones Graecae, Nr. III, pl. 701, 702 and 739).

In spite of the numerous references that we have on this event, very little, if anything at all can be said about the nature and the origin of the seismic sea-wave of $142 \mathrm{AD}$, it seems, however, that the seat of the wave was not very far from the city of Rhodes, since it surged the city before " these still alive from the earthquake shock had time to move and search for their missing relatives". Apart from this and from the fact that the wave was not much felt by sailing ships not more than 50 miles from Rhodes, there is nothing else that the 7000 -words long narration of Aristides can tell us.

The only conclusion we can draw about the 142 AD seismic sea-wave is that its seat should not had been very far from the city of Rhodes, and most certainly on the northeastern side of the island.

5. 262 AD. South Coasts of Asia Minor (iv?) $7(v, 2.6) 31(p .499)$, 809 (p. 51).

From Trebellius Pollio we learn that in the consulship of $\mathrm{Li}$ cinius Gallionus desasterous earthquakes occurred in Asia Minor and in Lybia. Many houses collapsed causing a large number of deaths, and in many places large cracks opened into the ground, and clefts were formed. The sea overwhelmed many cities (Gallieni, lib. v, § 2-6). Trebellius says also that these earthquakes occured while a great pestilence raged in the east. The pestilence, which is also mentioned by Eusebius (Eccles. History, lib. vii, § 22) together with the fact that at that time Gallienus was consul, fixes the time of this event in $262 \mathrm{AD}$.

It does not seem certain that these earthquakes happened at the same time in Asia Minor and in Lybia. Nor that the inundations alluded to by Pollio took place in Asia Minor. We were unable to find a more detailed information to these events. 
6. 315. Dead Sea (iii). 24 (p. 100).

7. 342" AD. Cyprus. Famagusta. 39 (p. 140), 43. cf.: 12 (P. 30c, 31a), 1 (P. 183), 13 (P. 29), 8 (P. 298), 23 (11, 10), 17 (iii, 6), 45 (v, P. 169), 38 (ii, P. 343), 46, 40.

During the years 341 to 343 a series of destructive earthquakes occurred in the Southern coasts of Asia Minor and in the island of Cyprus. These events are mentioned by many chroniclers of the time (1), who do not agree on the date of the earthquake in Cyprus. A most interesting analysis of these texts was made by Sathas (1873), who proved beyond doubt that the earthquake in Cyprus should have occurred in $342 \mathrm{AD}$, and that minor seismic activity might have proceeded and followed this earthquake. Allowing for natural exaggerations, there can not have been much of Salamis in Cyprus left standing after this, and the emperor rebuilt it as Constantia (Sathas 1873). Paphos was so badly damaged, that it was not for some time rebuilt (2).

In many earthquake catalogues we find the information that during this earthquake Salamis was flooded by a seismic seawave, but we can find no reference to such an event in the chronics of the time (1), except in Oberhummer's work (p. 140) who missinterprets Malalas's statement on this earthquake. Malalas says:

«... in the reign of Constantinus Chloros (3), Salamias (Salamis) in Cyprus suffered; the earthquake made the largest part of the city to sink into the sea and threw the rest of it on the ground ...» (p. 313).

Oberhummer in transcribing the Greck text from Malalas omit-

(1) Malalas (lib. xii, §O. 415), Theophanes (p. 30c, 31a), Eusebius (Chronicon p. 183), Anastasios (p. 29), Cedrinos (p. 298), Socrates (H.E. ii, 10), Sozomenis (iii, 6), Sigonius (lib. 5, p. 169), Orosius (Bibl. Patrum, vol. 6, p. 442), Muratori (Ann. d'Italia, vol. 2, p. 343).

(2) Hicronymus "Vita St. Hilarionis " Migne's Patrologia Latina, vol. 23, col. 50 .

(3) Cl. Sathas (1873), p.p. $\gamma_{i}{ }^{\prime} v^{\prime}$, Unger-Kotschy (1865) p. 60. 
ted three words from the third line (1), so that the translation of the text reads "the city was overwhelmed by the sea (2)". The complete text, however reads "the city sunk into the sea", which, as it should, does not allude to a seismic sea-wave.

It appears, therefore, that this missinterpretation of Malalas's statement by Oberhummer, lead later authors to believe that the 342 earthquake in Cyprus was accompanied by a seismic seawave. It is quite clear, however, that the result of the 342 earthquake was to make part of the city of Salamis to slump and sink into the bay of Famagusta, in a similar manner as Helice did in the Gulf of Corinth in $373 \mathrm{BC}$.

8. 344 AD. Dardanelles (Hellespont) and Niksar (Neocaesaria) (iv) Thracian Coasts (iil). 8 (p. 298c), 45 (v, P. 110, line 36).

A few years later a violent earthquake in Hellespont devastated Niksar (Neocaesaria). This event is mentioned by many historians (3) but Cedrinos and Sigonius refer in addition to a convulsion both at sea and on land as a result of which the city of Neocaesaria "drowned into the sea" (4). It is not clear whether Cedrinos's statement refers to an inundation. From Sigonius's narration, however, it seems most probable that Neocaesaria was flooded by the sea.

No detailed account on this event was found.

According to the writers in the Corpus Scriptorum Historiae Byzantinae, the year of this event must be 344 AD. Both Mallet

(1) The Pertinent Greek text in its complete form is: «... Уuisupus

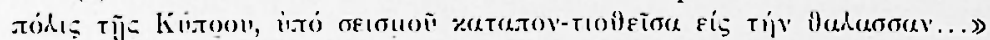

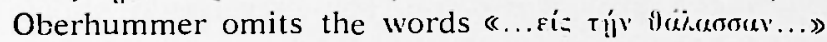

(2) Oberhummer concludes that «... жuтuтovтібi)e or... Der Ausdruck lässt erkanhen, das auch in diesem Falle die werheerendste Wirkung von einer Flutwellc ausging ". (p. 140).

(3) Hieronymos (Ann. 2360); Theophanes (p. 31a); Nyssensianos Gregorios (vol. 3, p. 554 bc); Eusebios (p. 252); Cedrinos (p. 298c); Frytschius (p. 347); Sigonius (lib. v, p. 110, line 36).

(4) «... pontistheisa kateptôthi...» Cedrinos

"... mari absorpta..." Sigonius 
(1858) and Perrey (1850) date this event one year too low and miss Cedrino's statement.

9. 348 AD. Syrian coasts. Beirut (iii?), Arwad Islands (iii?). 43 (p. 199). Not found in contemporary writers.

10. 362 AD. Dead Sea. Jordanian coasts (iii?). 43 (p. 192), 44 (p. 801). No authority is quoted. Chronographers of the time who describe the earthquake do not mention a seismic sea-wave, 3 (xxiii, 13), 27, and cross-references in $42(p .148)$.

11. 365 AD. July 21, Eastern Mediterranean, Methone, Epidaurus, Crete (iv), Beaotian Coasts, Adriatic Coasts, Epirus, Alexandria, Sicily (iii +). 3 (xxxi, 10.15), 15 (i, P. 349), 8 (P. 310c, d, 314c, d), 10 (P. 255c), 12 (P. 47d), 11 (xiii), 9 (P. 310b), $16(i$, 521, 621), 25a (P. 65), 28 (iv, p. 187), 31 (P. 526), 29.

In $365 \mathrm{AD}$ an earthquake occurred in Greece which was followed by a desasterous seismic sea-wave. This event is mentioned by many writers (1). Thousands of people were drowned and the waves leveled many towns on the coasts of Crete, Peloponnesus, Boeotia, and even as far as Alexandria and Sicily.

From Marcellinus, Cedrinos, Theophanes, Calvisius and Bollandus we learn that... "A little before sunrise on the 21st of July, in the first consulship of Valentinian, there was a terrible earthquake. The sea was driven back and its very depths were uncovered. Many marine animals were left sticking in the mud. The depths of the sea, its valleys and the recesses of its hills, which since creation had been lying beneath the boundless waters, now beheld the first beams of the sun. The earthquake shook the whole world. In Alexandria the sea carried ships over the great

(1) Amminanus Marcellinus (Hist. Rom., lib. xxvi, § 10.15-19); Hieronymos (Vita Hilarionis, vol, 1, p. 394); Cedrinos (p. $310 \mathrm{~cd}$, p. $314 \mathrm{~cd}$ ); Socrates (lib. iv, § 3); Theophanes (p. 47 d); Paschalis (Chron., p. $301 \mathrm{~d}$ ); Malalas (lib. xiii); Libanius (Epit. Julianii, vol. 1, p. 521, p. 621); Orosius (lib. xii, $\S 32$ ); Calvisius (p. 526); Bollandus (Acta Sanct.); Baronius (Ann. Eccles., vol. iv, p. 187); Sigonius (Occid. Imp. I, lib. v, p. 236). 
walls, while in other places it stranded them on the dry shore. In the Adriatic sea ships were stranded until the sea came back again. Other vessels of great size were driven on shore and cast upon the housetops, as happened in Alexandria. Some were even driven two miles inland, of which I myself (Marcellinus) saw one in Laconia, near the town of Methone, which was lying and rotting where it had been driven. Many places in Crete, Achaia, Bocotia, Epirus and Sicily perished under the sea which rose and rushed inland up to the foothills of the mountains 12 miles from the shore. Places where in the past were ment for pedestrians, became navigable and new places appeared from the sea. Five thousand people perished in Greece, since when the sea retired people straggled about the shoals picking up fishes and things of that kind. In another quarter (?) the waves came back, swelling over the boiling shallows, beat upon the islands and coasts of the mainland, leveling cities wherever they encountered them. In Epidaurus, Saint Hilarion is said to have stopped the waves from flooding the town by standing on the shore immediately after the sea had retired. In other places, however, near Epidaurus, the wave leveled many towns and the bodies of those who perished flcated about in the shallows on their backs and faces".

In this, and in other descriptions of the event, it is of interest to notice how little is mentioned of the damage which was caused by the earthquake shock proper. Apart from Crete, where a number of towns in the interior of the island is said to have been damaged (1), no other town seems to have been damaged by the shock itself. This, to our mind, indicates that the seat of the earthquake shock should have been at some distance from the land, at sea; most probably somewhere between Crete and the southwest coasts of Peloponnesos in the vicinity of the Ionian fault. Such a position of the earthquake seat would easily account for the unopposed propagation and great magnitude of the wave on the southern coasts of Peloponnesos, in the Adriatic sea and on the coasts of Alexandria. Also, the fact that a considerable ti-

(1) We are inclined to think that this damage was produced by another earthquake, probably by that mentioned by Libanius, Socrates, and $\mathrm{Si}$ gonius, for $368 \mathrm{AD}$. 
me should have elapsed between ebb and flow in places such as Epidaurus, Adriatic sea, Alexandria and Asia Minor indicates that the seat of the sea-wave, if it coincided with that of the earthquake, should have been at a considerable distance from these places.

Apart from Theophanes and Cedrinos who date this event one year too high, all the others agree for the year $365 \mathrm{AD}$.

12. 447 AD. November. Sea of Marmara. Marmara islands, Dardanelles and the Coasts of Marmara (iv -), Constantinople (iii). $49(i, 17)$.

During the beginning of November $447 \mathrm{AD}$, a disasterous earthquake occurred in Constantinople. The shock was felt in Thrace, Phrygias, Troad, Bithynia and in the Hellespont and caused heavy damage. This event is described in many contemporary writings (1), and from Evagrios we learn that:

" ...during the reign of Theodosius, a horrible earthquake occurred in his dominion. The shock was so violent that many fortresses were thrown to the ground and the long walls at Kherronisos collapsed. In many places chasms opened into the ground and many towns perished in them. Many other misfortunes occurred, both on land as well as at sea. Springs ceased to flow and new ones burst forth. Trees were flung up roots and all and land-slides changed the shape of mountains. From the sea dead fish was hurled violently on shore and many islands were inundated; and when the sea retired sailing ships were left standing on shore. The two Phrygias Bythinia and the Hellespontos suffered. This calamity persisted for a long time, though not with the same violence as it began; with time the shaking faded out until it stoped... " (lib. i, § 17) (2).

(1) Chronicon Paschali (p. 317); Theophanes (p. 93); Malalas (p. 353); Evagrios (lib. i, § 17); Marcellin.

(2) Free translation. 
This earthquake seems to have centered on the northern part of the Marmara area, and although Evagrios does not name the islands which were flooded by the sea-wave, it seems probable that they were the islets in the Sea of Marmara.

All historians concerned agree in the date of this event which can be placed in the first week of November $447 \mathrm{AD}$ (1).

13. 450 January. Sea of Marmara, Constantinople (iii). 9 (p. 572), 31 (p. 552).

Many Historians (2) of the time mention an earthquake in Constantinople which occurred in January 450. From their narrations it appears that the shock was not very severe and that no damage of any magnitude was caused. Except Lycosthenes (1557) none of the authorities consulted mentions a seismic seawave. Lycosthenes, most probably refering to the earthquake at Constantinople of 447 , says that:

" ...the earth opened in many chasms, and many cities in Asia were overthrown. The sea abandoned its shores and fire appeared in the sky. The earthquake lasted for six months... ".

\section{ACKNOWLEDGMENTS}

I have been much assisted by Professor N. Ambraseys of the Imperial College - University of London - to whom I am indebted.

Without his invaluable help this work could not have been carried out.

(1) Lycosthene $(1557,454)$ places this event nearly seven years too high. Being aware of the chronological inconsistencies involved in his work we disregarded this information. Calvisius (p. 551) dates this event 24 September 446.

(2) Paschalis (p. 318-19); Mathias (p. 378); Calvisius (p. 552). 


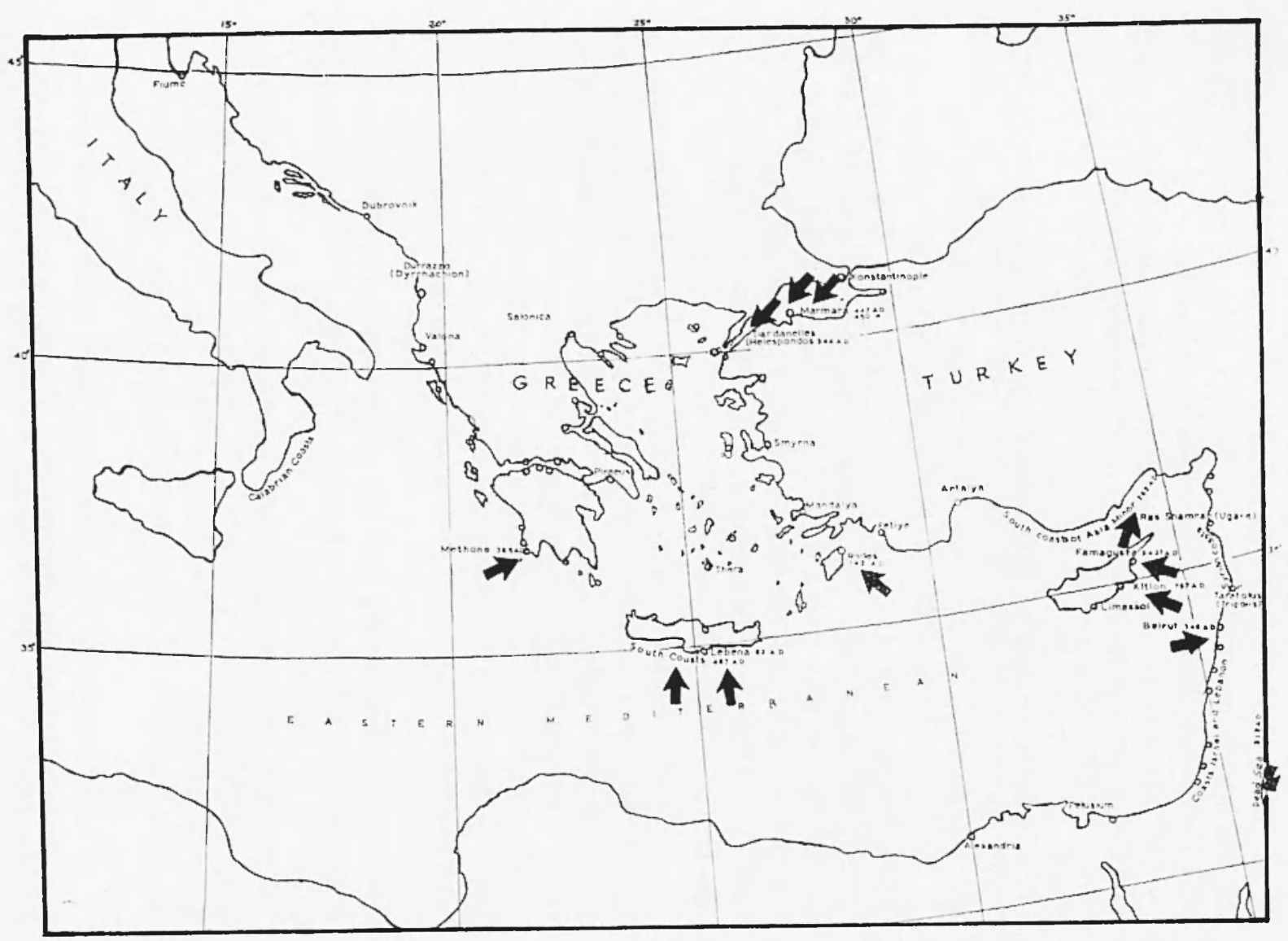

Tsunamis of the Eastern Mediterranean (known or inferred). From birth of Christ to 500 A.D. $\mathrm{o}=$ main region in which the tsunami was felt. 


\section{REFERENCES}

\section{CLASSICAL SOURCES}

1 Eusebios, Pamphilios - Opera historia ecclesiastica.

2 Julius, Capitolinus - Antonius Pitis.

3 Marcellinus, Ammianus - Rerum gestarum.

4 Pausanias - Graeciae descriptio.

5 Philostratos - Vita Apollonii.

6 Strabo - Geographica.

7 Trebellius, Folio - Gallieni.

8 CEDRINos - Cedrinos Georgios compendium historiarum.

9 Cedrinos - Chronicon Paschale.

10 Glycas - Michaelis Glycae annales.

11 Matalas - Chronographia Ioannis Malalae.

12 Theophanes - Theophanis Abbatis Agri atque Confes. Chronographia.

13 Anastasios.

14 Elias Nisibinos.

15 Hieronymos.

16 Libanius.

17 SOZOMENIS.

18 Syncellos.

19 Aristides, Aelios, 145 A. D. - Rhodiakos. In J. Mason's “ Collectanea historica ad Aristidis vitam », (Ed. Dindorf, vol. 1, Part. 2, lib. 43, c. 340-374, Bonn 1722).

20 Eusebios, Pamphilios, c. 330 A.D. - Armenian Text: in C. Coenobi's "Chronicon », Ed. Aaronis, Venice, 1868. 
21 Evagrios, Scholastikos. In J. Bidez's "Ecclesiastic history ", Ed. Methuen, London 1898; also in PCCGL and PCCL.

22 Crosius, Paulus, 416 A.D. - Historiae adversum paganos libri vii. In C. Zangenmeister's Edition, Ausburg 1570; also in BSGR, PCCL, and in "King Alfred's Anglo-Saron version of the history by Orosius ", translated by J. Bosworth, Longman's Edition, London 1859.

23 Sccrates, Scholastikos, 5th century A.D. - In A. Cousin's " Histoire de l'église ", Paris 1636; also in PCCGL.

\section{ARABIC SOURCES}

24 Stepan ACOGH'ig of Diron. - In E. Dulaurier's translation of the Armenian text "Acogh'is universal history ". Publications de l'Ecole des langues Orientales Vivantes, vol. 18, p. 101-102, Paris 1898.

25 Jirgis Abu'l Faraj ign-al-'Ibri (Bar Hebraeus): (a) Mahkhtebhanth zabhne. In P. BEDJun's Srriac Text, Maisonneuve Edition, Paris 1800; also in E. A. W. Balce's "Chronography ", Oxford Univ. Press, 1932. (b) Historia compediosa dynastiartm. Translated into Latin by E. Pocock, H. Hall's Edition, Oxoniae 1663.

\section{CONTEMPORARY SOURCES}

26 Amibraseys N., 1962 - Dala for the investigation of the seismic sea-waves in the Eastern Mediterranean. Bull. Seism. Soc. Am., 52, No. 4, pp. 895-913, October, 1962.

27 Arvinitakis, G.L., 1903 - Essai sur le climat de Jérusalem. "Bull. de l'Institut Egypt ». 4, Series iv, p. 179. Cairo.

28 Bironius, C., 1603 - Annales ecclesiastici a Christo nato ad annum 1198. Ed. Borenius, vol. 4, p. 187, Antverpia.

29 Bollanidus J., Henschen G., 1858. - Acta sanctortum Bollandiana. 9, Book 9. Chapt. 27, 56, Brussels.

31 Bursinn, C., 1852. - Geographe von Griechenland. Ed. Teubner, 2, p. 522, Leipzig.

31 Calvisius, S., 1650 - Opus chronologicum ubi tempus astronomicum per motus etc... 4th Edition Anth. Humnius, Francofurti ad Hoenum et Embdae. 
32 Calanopoylos A., Bacon E., 1969. - Atlantis, The truth behind the legend. Thomas Nelson and sons LTD London.

33 Heberdey R., 1890. - Der Einfall der Kostoboker in Griechenland. Archäologische-Epigraphische Mittheilungen aus Oesterreich-Ungarn, fol. 13, p. 191, Wien.

Hertzberg, G.F., 1866. - Die Geschichte Griechenlands under der Herrschaft der Römer. "Ed. Menzel ", 2, p. 92, 364, Ealle.

HoFf, K. von, 1841 - Chronik der Erdbeben und Vulkan-Ausbriiche, mit vorausgehender Abhandlung über die Natur dieser Erscheinungen. Gesch. Ueberlieferung nachgew. natürl. Veränder. Erdoberfläche, Parts 4 and 5 , Gotha.

LoEwy, E, 1888 - Griechische Inschrifttexte für akademische Ubungen ausgewänlt. 2nd Edition, p. 145, Praga.

36a LippINCOTT, 1952. - The Columbia Lippincott gacetear of the world. Ediz. L.E. Seltzer, 1952 Edition, Columbia Univ. Press. N.Y.

37 Mirinos G., Melidonis N., 1971. - On the strength of seaquakes (Tsunamis) during the prehistoric ertuptions of Santorin. Institute of Geology and Subsurface Research. (From the acta of the 1st International Scientific Congress on the volcano of Thera, Athens, 1969).

38 Niuratori, L.A., 1731. - Rerum Italicartm scriptores. 28 vols., Mediolani.

39 Oberhummer, E., 1903. - Die Insel Cypern. Eine Landeskunde auf Historischer Grundlage. Ed. Th. Ackermann, München.

40 Sathas, K.N., 1875. - Chronographers of the Kingdom of Cyprus, "Mesaionike Vivliotheki ", 2, Prologos, Venice (in Greek).

41 Savary, C.E., 1788. - Letters on Greece. Ed. J. Robinson, p. 168, London.

42 Schmid, J., 1879. - Studien ïber Erdbeben. Ed. Alwin Georgi, Leipzig.

43 SiEBerg, A., 1932. - Untersuchungen über Erdbeben und Bruchschollenban im östlichen Mittelmeergebiet. Denkschriften der Medizinish-Naturwissenschaftlichen Gesellschaft zu Jena, vol. 2, Jena.

44 Sir:Berg, A., 1932. - Die Erdbeben. In B. Gutenberg's Handbuch der Geophysik, vol. 4, Berlin, Ed. G. Borntraeger.

45 Sigonius, C., (1579) "Historiarum de Occidentali Imperio" Ed. Orf. Thomae Guarini, 20 vols., Basileae.

46 Unger F., Kotschy TII., 1865. - Die Insle Cypern. Ed. W. Braumüller, p. 60-1, Wien. 